\title{
Effect of Lignosilicon on the Content and Antioxidant Activity of the Polyphenols of Buckwheat Fagopyrum esculentum Moench
}

\author{
Lebedeva G. ${ }^{1}$, Roze L. ${ }^{1}$, Lauberts M. ${ }^{1}$, Jasina L. ${ }^{1}$, Rancane S. ${ }^{2}$, Telysheva G. ${ }^{1 *}$ \\ 1 - Latvian State Institute of Wood Chemistry, 27 Dzerbenes, Riga, LV-1006, Latvia \\ Phone.:+(371)6555916, fax: +(371)67550635, e-mail: ligno@edi.lv; lclgl@edi.lv \\ 2 - LUA Research Institute of Agriculture, Zemkopibas Inst. 7, Skriveri distr., LV-5125, Latvija. \\ Phone: +(371)26484676, fax: +(371)65197954, e-pasts: sarmite.rancane@ inbox.lv, * corresponding
} author

\begin{abstract}
Lignin preparations, introduced into soil jointly with buckwheat Fagopyrum esculentum Moench, variety 'Aiva' (cultivated throughout Latvia) seeds during the sowing in quantities of $20 \mathrm{~kg} \mathrm{ha}^{-1}$ and $40 \mathrm{~kg} \mathrm{ha}^{-1}$, exerted a favourable effect on the ned in alcohol extracts from the biomass of different morphological parts of buckwheat, were represented mainly by rutin. The content of rutin in the ethanol extracts from the biomass of flowers with bract reached the maximum values in the phase of accomplishing blooming - beginning of fruit formation to be $2.74 \%$ in terms of dry mass (exceeding the rutin content development of plants and the synthesis of flavonoids in flowers with bract. Flavonoids, determin the control by $65 \%$ ) in the variant with $40 \mathrm{~kg} \mathrm{ha}^{-1}$ of Lignosilicon. Lignin preparations favoured the increase in the radical scavenging capacity of the alcohol extracts of the biomass of flowers with bract of buckwheat, as well as grain and hulls. The increment of the buckwheat grain crop, in comparison with the control on the background of $40 \mathrm{~kg} \mathrm{ha}^{-1}$ of lignin, was $12 \%$, and that on the background of $20 \mathrm{~kg} \mathrm{ha}^{-1}$ and $40 \mathrm{~kg} / \mathrm{ha}$ of Lignosilicon $10 \%$ and $15 \%$, respectively.
\end{abstract}

Keywords - buckwheat, lignin, Lignosilicon, flavonoids, rutin, antioxidant activity, crop.

\section{INTRODUCTION}

Systematic studies on the effect of silicious lignins (Lignosilicon) on the growth and development of different agricultural plants are under way at the Latvian State Institute of Wood Chemistry. Lignosilicon, applied as fertilizers and growth activators in cultivating cereals (oats, wheat, rye, maize) [1-3], legumes /Leguminosae/ leguminous plants (red clover) $[4,5]$ and Solanaceae plants (tomato, potato) $[6,7]$ exerted a favourable effect on the development of plants, on the enhancement of their productivity and the qualitative characteristics of agricultural products. The results of the studies, performed jointly with the LLU Research Institute of Agricultury (Skriveri, Latvia) with plants of buckwheat, variety "Aiva" have demonstrated a favourable effect of Lignosilicon (LSi), introduced into soil $\left(10 \mathrm{~kg} \mathrm{ha}^{-1}\right.$ and $\left.20 \mathrm{~kg} \mathrm{ha}^{-1}\right)$ simultaneously with the sowing of seeds, on the activation of the development of the aboveground and root system of plants, on the grain crop and the yield of straw [8].

Buckwheat is a cereal belonging to the Polygonaceae family. The fatherland of buckwheat is believed to be Northern India. At present, interest in both wild tartary buckwheat Fagopyrum tataricum, cultivated in countries of South-Eastern Asia (China, India), and Central and Southern Italy, and common buckwheat Fagopyrum esculentum has grown [9-11].
Thanks to the activities of the International Buckwheat Research Association (IBRA), tartary and common buckwheat have become the object of versatile research [9].

Big work is under way in countries of SouthEastern Asia (China, India) on selecting tartaric buckwheat, and obtaining food products and physiologically active substances from different morphological parts of the plant $[10,11]$. The world's leaders of the production of common buckwheat at the beginning of the XXI century are Russia, China and Ukraine. In Western Europe, the leader is France, where relatively small areas are sown, but the highest crops are obtained $-3.5 \mathrm{t} \mathrm{ha}^{-1}$. The buckwheat grain crops worldwide, except in France, are not high and on average range from $0.8 \mathrm{t} \mathrm{ha}^{-1}$ to $1.2 \mathrm{t} \mathrm{ha}^{-1}$ [12] According to the data of FAOSTAT (Food and Agriculture Organisation of the united Nations), the sown area of buckwheat was 2.5 million ha in 2008 [12]. In Latvia the sown area under buckwheat in 2009-2011 was $1 \%$ from all spring crops and in 2011 buckwheat occupied 9.5 thousand ha. The average yield of buckwheat grain in Latvia was 0.48 tha $^{-1}, 0.56$ $\mathrm{t} \mathrm{ha}^{-1}$ and $1.0 \mathrm{t} \mathrm{ha}^{-1}$ in 2009, 2010 and 2011, respectively [13]. The reason for the low crops of buckwheat are the biological peculiarities of the culture [12-15] which is very sensitive to weather conditions, long and disunited periods of flowering 
and maturing and the weak homeostasis of grain formation. Buckwheat has a complex of unique properties useful for the life and health of humans [1012, 14] incl. mineral elements (phosphorus, calcium, kalium, iron, zink, copper) and vitamins $\left(\mathrm{P}, \mathrm{B}_{1}, \mathrm{~B}_{2}, \mathrm{~B}_{\mathrm{C}}\right.$ $\mathrm{PP})$. Buckwheat grain, has an unique amino acid composition of protein in comparison with other grain cultures. Interest in buckwheat as a medicinal plant rich an antioxidant rutin is growing [10-12, 14-21] owing to its pronounced capillary strengthening, hepaprotective, nootropic [22], anti-diabetic, anticancer and anti-mutagenic action [10]. For obtaining rutin-containing preparations, the flowers with bract, leaves and pericarp of buckwheat seeds are used. The highest content of rutin in inflorescences and leaves in the stage of accomplishing blooming - beginning of fruit formation is observed [17, 22]. According to the technical documentation of different countries the plant biomass can be considered as raw material for pharmacy if rutin content is not less than $2.5 \%$ (Russian Federation) [22], and more that 3\% (in France) [23]. The rutin content in various morphological parts of the buckwheat plant is influenced by numerous factors such as environmental conditions, lighting intensity, moisture supply, etc. $[10,14,16]$. For the European region, urgent is the search for the pathways of the activation of the development of common buckwheat plants, the enhancement of the crop capacity and quality, the increase in the content of antioxidants, firstly flavonoids (incl. rutin) of this valuable culture. One of the ways is the use of plant growth and development activators [24-27]. This was demonstrated in microfield conditions at pre-sowing treatment of seeds and spraying of the plants. Among the exogenous growth regulators were tested: Emistin (a product of the metabolism of the symbiotic fungus Acremonium lichenicla, isolated from ginseng), epibrassinolide (an analogue of phytohormones - brassinosteroids), Ecost (a composition on the basis of high-disperse silica with microelements) [24], Circon (a mixture of hydroxycinnamic acids, isolated from purple coneflower Echinacea purpurea), Corvitol (active acetylene alcohol) [25], the preparation on the basis of the strain of the bacteria Halobacterium salinarum (the active substance - a fragment of the retinal's molecule), ethanol extract of the seaweed L.Cichorioides was tested [27]. The pre-sowing treatment of buckwheat seeds with an ethanol extract of seaweed under conditions of the microfield experiment activated the growth of the plant seedlings and the rutin content (from $1.8 \%$ to $2.2 \%$ ) in the green mass of the plants of buckwheat Fagopyrum esculentum Moench.

The objective of the study was to evaluate the effect of lignin (L) and Lignosilicon (LSi), synthesised on its basis, introduced into soil jointly with seeds during the sowing of buckwheat Fagopyrum esculentum Moench, variety "Aiva", on the content and antioxidant activity of polyphenols in 3 morphological parts of the plant: in the biomass of the flower with bract, in grain and in hulls.

\section{MATERIALS AND METHODS}

Culture - buckwheat Fagopyrum esculentum Moench, variety 'Aiva', cultivated throughout Latvia. This is the only variety registered in this country. Duration of the vegetation period from the instant of emerging seedlings to technical maturity: 67-73 days. Seeds sowing rate: $70 \mathrm{~kg} \mathrm{ha}^{-1}$. Average yield of grain of this variety in conditions of Latvia is: $2 \mathrm{t} \mathrm{ha}^{-1}$, potential crop capacity can achieve $3 \mathrm{t} \mathrm{ha}^{-1}$.

Lignin products: $\mathrm{L}$ - hydrolysis lignin with the content of Klason lignin of $72 \%$. LSi - Lignosilicon a product with a silicon content of $5 \%$, synthesized on the basis of hydrolysis lignin.

Lignin preparations were introduced into soil jointly with seeds during the sowing with the rates of $20 \mathrm{~kg} \mathrm{ha}^{-1}$ and $40 \mathrm{~kg} \mathrm{ha}^{-1}$.

Microfield experiment with buckwheat was started on 2 June, 2011 in experimental plots of the Research Institute of Agriculture (Skriveri, Latvia) after 2 years of red clover cultivation. Soil - sod-podzolic (humus content $2.1 \%$ ), granulometric composition - loam, $\mathrm{pH}$ KCL 6.0, content of plant available nutrients $\mathrm{P}_{2} \mathrm{O}_{5}$, $106 \mathrm{mg} \mathrm{kg}{ }^{-1}, \mathrm{~K}_{2} \mathrm{O}-141 \mathrm{mg} \mathrm{kg}^{-1}$. Additional amount of macro- and micro- nutrition elements did not used.

4 variants of experiments were established in triplicate. The area of one experimental plot was 45 $\mathrm{m}^{2}$.

Sowing of seeds was performed using a seedling machine "Hege". Before sowing, the seeds were mixed with lignin products. The crop was harvested by a "Wintersteiger" combine.

During the vegetation process (in 28 and 60 days after the sowing), phenological observations of the plants were performed. The plant length, the number of side branches, inter-nodes and inflorescences, and the mass of the above ground part and roots were determined. For measuring the length and thickness of the $1^{\text {st }}$ inter-node, an Electronic Digital Caliper was used.

Samples of the biomass of flowers with bract for determining substances of phenolic nature therein were taken in the bloom phase (48 days after the sowing) and in the phase of accomplishing blooming beginning of fruit formation (60 days after the sowing) in triplication.

The total polyphenol content in the ethanol extracts from the raw biomass of flowers was determined by the Gallic Acid Equivalence method (GAE) using the Folin-Ciocalteu phenol reagent (FCR). The FCR assay relies on the transfer of electrons in alkaline medium from phenolic compounds to phosphomolybdic-phosphotungstic acid complexes (reducing them to molybdenum blue), which are determined spectroscopically at $765 \mathrm{~nm}$. 
This assay was performed in $15 \mathrm{~mL}$ test-tubes and assessed in an UV/VIS Spectrometer Lambda 25 (PerkinElmer Instruments).

To evaluate the summary antioxidant activity the DPPH• (2,2-diphenyl-1-picrylhydrazyl) radical scavenging assay described in [28] was used. $0.03 \mathrm{~mL}$ of a sample solution in methanol/ethanol (with a known mass concentration of the dry matter of the extract) was mixed for 15 min with $3.0 \mathrm{~mL}$ of a $1 * 10^{-4}$ mol L ${ }^{-1} \mathrm{DPPH} \cdot$ methanol solution, and then the absorbance at $517 \mathrm{~nm}$ of the mixture was immediately measured using a Perkin Elmer Lambda 25 UV/VIS spectrometer. The inhibition percentage (IP) of the radical species was calculated as follows:

$$
I P=\frac{\left(A_{B}-A_{A}\right)}{A_{B}} \times 100 \%
$$

where $A_{B}$ is absorbance in blank probe (antioxidant was omitted) and $A_{A}$ is absorbance in the sample after 15 min. Using different concentrations of extracts, the dependence of the IP values on the antioxidant concentration was established and used for the calculation of $\mathrm{IC}_{50}$ (the concentration of the tested sample required for a $50 \%$ inhibition of radical species). To calculate the $\mathrm{IC}_{50}$ values, the linear regression analysis was made, using SPSS Statistics 17.0 (level of significance 0.05). According to the definition, higher antioxidant activity results in lower value of $\mathrm{IC}_{50}$.

HPLC analysis [29] was performed with HPLC Agilent Technologies 1100 Series coupled with an UV diode-array detector. The separation of the analytes was done with a column Zorbax Extend - C18, $4.6 \mathrm{x}$ $250 \mathrm{~mm}, 5 \mu \mathrm{m}$. Two eluents were used: water with $0.1 \%$ formic acid (v/v), 5\% methanol (v/v) (A) and methanol (B). The elution conditions were 0-5 min $30 \% \mathrm{~B} ; 5-25$ min from $30 \% \mathrm{~B}$ to $70 \% \mathrm{~B} ; 25-29 \mathrm{~min}$ $100 \% \mathrm{~B} ; 29-30 \mathrm{~min}$ from $100 \% \mathrm{~B}$ to $30 \% \mathrm{~B}$. The operating conditions were: column temperature $30{ }^{\circ} \mathrm{C}$; injection volume $10 \mu \mathrm{L}$. The components were detected by absorbance at $355 \mathrm{~nm}$. The flavonoids calibration curves were made by diluting flavonoid solutions with methanol to give the concentration of the standard in the range of $10-100 \mathrm{mg} / \mathrm{L}$. The curves were plotted from chromatograms as a peak area $v s$. the concentration of the standard. The concentrations of rutin, quercetin and quercitrin were calculated from their standards (Sigma Aldrich, HPLC purity $\geq 94 \%$ ).
Weather conditions of the vegetation period of 2011 were favourable for the development of buckwheat plants [30]. The seeds were sown into the soil, supplied well with moisture; mean temperature in June, July, August and September was $17.8{ }^{\circ} \mathrm{C}, 20.2$ ${ }^{\circ} \mathrm{C}, 16.9{ }^{\circ} \mathrm{C}$ and $12.8{ }^{\circ} \mathrm{C}$, respectively. The moisture supply of soil, except for the end of August beginning of September, was favourable. Because of the rains in the 3rd decade of August and the 1st and 2nd decades of September, the crop was harvested with a 10-15-day delay (29.09.2012). Grain losses due to its fall, especially in the variant with Lignosilicon, are possible.

\section{RESULTS AND DISCUSSION}

Visual differences in the development of plants growing on the background of lignin products began to manifest themselves in the phase of bud formation: in 28-30 days after sowing when blooming has not yet began (Fig.1). The plants were developed best on the background of $40 \mathrm{~kg} \mathrm{ha}^{-1}$ of LSi. The green mass of the above ground part of the plants in the variant with LSi $40 \mathrm{~kg} \mathrm{ha}^{-1}$ in 28 and 60 days (the phase of blooming - beginning of fruit formation) after the sowing exceeded the values of the green mass in the control by $40 \%$ and $37 \%$, respectively. In the variant with LSi $20 \mathrm{~kg} \mathrm{ha}^{-1}$ increase in green mass in comparison with the control is significantly lower, namely, by $13 \%$ and $8 \%$, respectively (Table 1 ). On the background of lignin, the plants were also developed better than in the control variant, but worse than on the background of LSi. The number of flower clusters in plants in the bud phase in variants: L, LSi $20 \mathrm{~kg} \mathrm{ha}^{-1}$ was on the level of control, and in the variant with LSi - $40 \mathrm{~kg} \mathrm{ha}^{-1}$, it exceeded the value in the control by $24 \%$. The number of the flower clusters in plants in the variant with LSi $40 \mathrm{~kg} \mathrm{ha}^{-1}$ in the phase of blooming - beginning of fruit formation was also the highest and exceeded the value in the control by $38 \%$. In comparison with the control in other variants, in the variant with LSi $40 \mathrm{~kg} \mathrm{ha}^{-1}$, a greater number of bolls/fruits has formed. The least number of bolls/fruits has formed in the control variant and the variant $L$. The development of plants on the background of LSi $40 \mathrm{~kg} \mathrm{ha}^{-1}$ was distinguished for better parameters during the whole vegetation period, incl. the phase of fruit formation. 


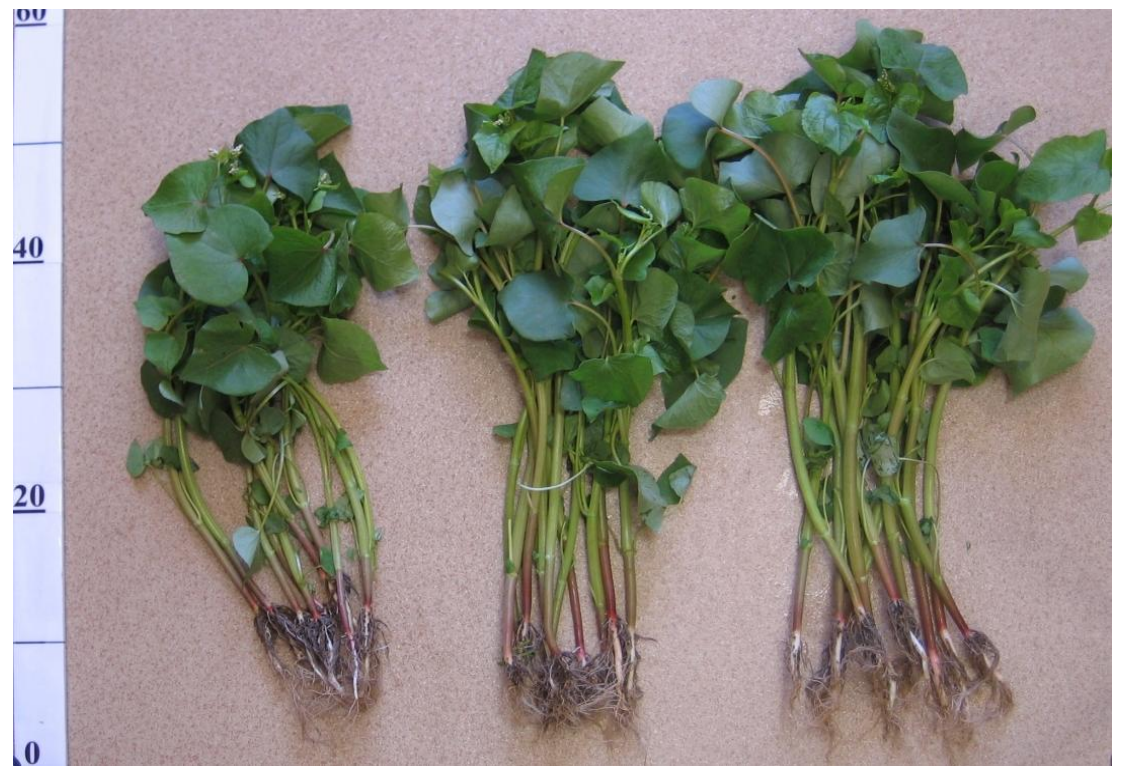

Fig.1. Effect of lignin product on the development of plants of common buckwheat Fagopyrum esculentum Moench, variety 'Aiva' in 28 days after the sowing - bud phase. From the left to the right, plants from the variants: control, $\mathrm{L}-40 \mathrm{~kg} \mathrm{ha}^{-1}, \mathrm{LSi}-40 \mathrm{~kg} \mathrm{ha}^{-1} .10$ plants are represented in each variant.

TABLE 1

EFFECT OF LIGNIN PRODUCTS ON THE CHANGE IN BIOMETRIC PARAMETERS OF PLANTS OF COMMON BUCKWHEAT FAGOPYRUM ESCULENTUM MOENCH, VARIETY ‘AIVA’ MICROFIELD EXPERIMENT, 2011

\begin{tabular}{|l|l|l|l|l|l|l|l|l|l|l|}
\hline Variant & $\begin{array}{l}\text { Rate of } \\
\text { lignin } \\
\text { products, } \\
\mathrm{kg} \mathrm{ha}^{-1}\end{array}$ & $\begin{array}{l}\text { Plant } \\
\text { length, } \\
\mathrm{cm}\end{array}$ & $\begin{array}{l}\text { Thickness } \\
\text { of the first } \\
\text { inter-node, } \\
\mathrm{mm}\end{array}$ & $\begin{array}{l}\text { Length of the } \\
\text { first inter-node, } \\
\mathrm{cm}\end{array}$ & $\begin{array}{l}\text { Number of } \\
\text { inter-nodes }\end{array}$ & $\begin{array}{l}\text { Number } \\
\text { of } \\
\text { branches }\end{array}$ & $\begin{array}{l}\text { Number of } \\
\text { inflorescences }\end{array}$ & $\begin{array}{l}\text { Green mass } \\
\text { of the plant } \\
\text { above ground } \\
\text { part, g }\end{array}$ \\
\hline $\mathbf{2 8}$ days after the sowing $(30.06 .2011)$ & \multicolumn{5}{|l|}{} \\
\hline Control & & 30.4 & 5.3 & 4.4 & 5.2 & 3.5 & 3.3 & 14.3 \\
\hline $\mathrm{LSi}$ & 20 & 36.8 & 5.3 & 4.9 & 5.0 & 3.6 & 3.7 & 16.2 \\
\hline $\mathrm{LSi}$ & 40 & 37.4 & 5.5 & 4.9 & 5.6 & 3.8 & 4.1 & 17.7 \\
\hline $\mathrm{L}$ & 40 & 37.2 & 5.4 & 4.6 & 5.7 & 3.7 & 3.8 & 14.8 \\
\hline$R S_{0.05}$ & & 2.82 & 0.63 & 0.64 & 0.40 & 0.79 & 1.00 & 2.30 \\
\hline $\mathbf{6 0}$ days after the sowing $(02.08 .2011)$ & 112.4 & 6.4 & 4.5 & 10.3 & 3.7 & 16.0 & 35.7 \\
\hline $\mathrm{Control}$ & & 113.3 & 6.7 & 5.4 & 10.5 & 3.7 & 19.2 & 38.5 \\
\hline $\mathrm{LSi}$ & 20 & 113.8 & 7.0 & 5.5 & 10.6 & 3.8 & 22.0 & 48.7 \\
\hline $\mathrm{LSi}$ & 40 & 114.0 & 6.9 & 4.7 & 10.2 & 3.8 & 20.0 & 46.3 \\
\hline $\mathrm{L}$ & 40 & 8.66 & 0.60 & 0.74 & 0.79 & 0.67 & 5.41 & 11.58 \\
\hline$R S_{0.05}$ & & & & & & & \\
\hline
\end{tabular}

Analysis of the ethanol extracts of the biomass of flowers with bract in the bloom phase (48 days after the sowing, more than $50 \%$ of plants bloom) and in the phase of blooming - beginning of fruit formation (60 days after the sowing) of plants has shown that the lignin products favoured the increase of the polyphenols content therein (Table 2). The most considerable distinctions are detected in the phase of blooming - beginning of fruit formation of plants. Against the background of L(40 $\left.\mathrm{kgha}^{-1}\right)$ and LSi (20 $\mathrm{kgha}^{-1}$ and $40 \mathrm{kgha}^{-1}$ ), the content of polyphenols in the ethanol extracts of flowers with bract exceeded their content in the control by $50 \%$ and $70-73 \%$, respectively. The content of flavonoids reached the maximum values in the phase of blooming - beginning of fruit formation. The rutin content in variants with L (40 kg ha ${ }^{-1}$ ) and LSi (40 kg $\mathrm{ha}^{-1}$ ) exceeded the control values by $25 \%$ and $65 \%$, respectively the quercetrin content - by $30 \%$ and $55 \%$, respectively. The results obtained showed that rutin was the predominant component of the flavonoid fraction in all buckwheat samples (Fig.2.) 


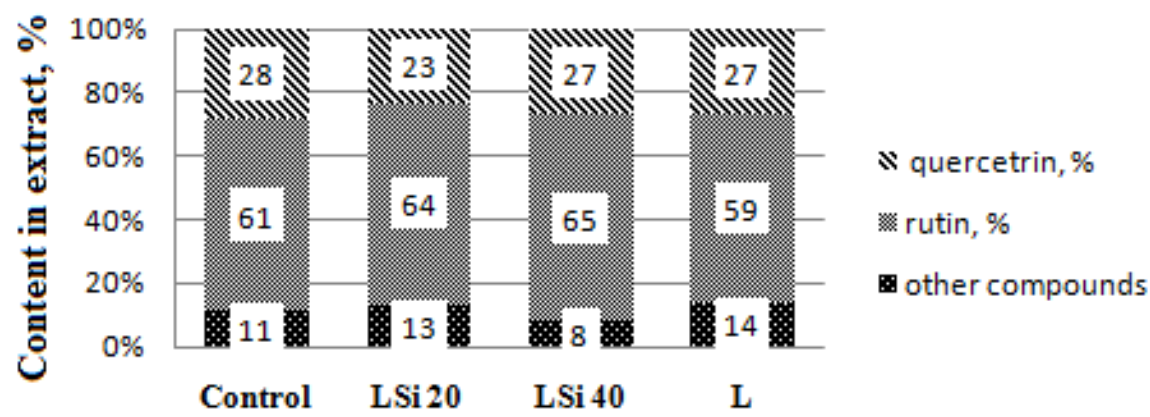

Fig. 2. Effect of lignin products on the content of flavonoids in the ethanol extract of the biomass of buckwheat flowers with bract, selected in the phase of blooming - beginning of fruit formation of the plants.

The rutin and quercetrin content in the extracts was more than $85 \%$. Buckwheat extracts, except the identified flavonoids, containig small amounts other compounds, which absorb at $355 \mathrm{~nm}$. In summary, the best results are obtained with LSi in the rate of $40 \mathrm{~kg}$ $\mathrm{ha}^{-1}$, because in this case the content of rutin, quercetrin and quercetin in the ethanol extracts was the highest.

Alcohol extracts of the biomass of flowers with bract of the buckwheat cultivated on the background of the lignin products demonstrated a higher radical scavenging capacity in the test with DPPH•, in comparison with the control. The radical scavenging capacity of the alcohol extracts of the biomass of flowers with bract was higher in the biomass, selected in the bloom phase of the plants and declined in the sample of the biomass of flowers with bract, selected in the phase of accomplishing blooming - beginning of fruit formation (Table 2) in spite of increase in flavonoids content in extracts and decline of total polyphenol content. Considerable distinctions in the indices of radical scavenging capacity in variants were observed for the extracts from flowers with bract, selected in the phase of accomplishing blooming beginning of fruit formation. Radical scavenging capacity for the extracts from variants $\mathrm{L}\left(40 \mathrm{~kg} \mathrm{ha}^{-1}\right)$ and LSi (40 kg ha ${ }^{-1}$ ) exceeded this index in the control by $40 \%$, and that in the variant LSi $\left(20 \mathrm{~kg} \mathrm{ha}^{-1}\right)$ by $16 \%$ (Table 2).

TABLE 2

EFFECT OF LIGNIN PRODUCTS ON THE RADICAL SCAVENGING ACTIVITY DETECTED BY DPPH• AND CONTENT OF POLYPHENOLS IN ETHANOL EXTRACTS OF FLOWERS OF COMMON BUCKWHEAT PLANT

\begin{tabular}{|c|c|c|c|c|c|c|}
\hline \multirow{2}{*}{ Variant } & \multirow{2}{*}{$\begin{array}{l}\text { Rate of lignin products, } \\
\mathrm{kg} \mathrm{ha}^{-1}\end{array}$} & \multirow{2}{*}{$\begin{array}{l}\text { Content of total polyphenols, GAE } \\
\text { g per } 100 \mathrm{~g}^{*}\end{array}$} & \multicolumn{3}{|c|}{ Content of flavonoids, $\% *$} & \multirow{2}{*}{$\mathrm{IC}_{50}, \mathrm{mgL}^{-1} * *$} \\
\hline & & & Rutin & Quercetrin & Quercetin & \\
\hline \multicolumn{7}{|c|}{48 days after the sowing } \\
\hline Control & 0 & $7.02 \pm 0.10$ & 0.93 & 0.40 & 0.010 & 15.4 \\
\hline LSi & 20 & $7.00 \pm 0.10$ & 0.97 & 0.43 & 0.010 & 14.2 \\
\hline LSi & 40 & $7.50 \pm 0.15$ & 1.07 & 0.47 & 0.011 & 13.6 \\
\hline $\mathrm{L}$ & 40 & $7.23 \pm 0.20$ & 0.71 & 0.27 & 0.007 & 13.5 \\
\hline \multicolumn{7}{|c|}{ Phase of blooming - beginning of fruit formation } \\
\hline Control & 0 & $2.60 \pm 0.10$ & 1.66 & 0.70 & 0.015 & 27.3 \\
\hline LSi & 20 & $4.5 \pm 0.10$ & 2.55 & 0.82 & 0.029 & 23.0 \\
\hline $\mathbf{L S i}$ & 40 & $4.40 \pm 0.10$ & 2.74 & 1.10 & 0.022 & 16.4 \\
\hline $\mathrm{L}$ & 40 & $3.90 \pm 0.15$ & 2.07 & 0.90 & 0.030 & 16.2 \\
\hline
\end{tabular}

It have to be pay attention that non-modified lignin applied at the same rate as LSi gave similar results. This fact allow to suggest the dominant role of phenyl propanoid structures in the effect observed.

Lignin preparations favoured the increase in the indices of the antioxidant activity of the alcohol extracts of the biomass of flowers with bract of buckwheat (Tabl. 2), as well as grain and hulls (Tabl.4). No correlation between the radical scavenging capacity and the rutin content and the total content of polyphenols was found, as mentioned in [18].

The conditions of the vegetation period of 2011 were favourable for cultivating buckwheat, which ensured a good development of the plants and a high crop (Table 3) that achieved the potential value pointed for this buckwheat variety $\left(3.0 \mathrm{t} \mathrm{ha}^{-1}\right)$. Because of the unfavourable weather conditions (rains), the crop was harvested with a 10-15-day delay, and a part of the fruits fell off, that decreased the waiting yield. 
TABLE 3

EFFECT OF LIGNIN PRODUCTS ON THE CROP CAPACITY OF BUCKWHEAT

\begin{tabular}{|l|l|l|l|l|}
\hline Variant & Rate of lignin products, $\mathrm{kg} \mathrm{ha}^{-1}$ & Crop, $\mathrm{t} \mathrm{ha}^{-1}$ & $\begin{array}{l}\text { Crop, } \% \\
\text { against control }\end{array}$ & Mass of 1000 grains, $\mathrm{g}$ \\
\hline Control & 0 & 3.00 & 100 & 26.2 \\
\hline $\mathrm{LSi}$ & 20 & 3.31 & 110 & 26.6 \\
\hline $\mathrm{LSi}$ & 40 & 3.45 & 115 & 26.7 \\
\hline $\mathrm{L}$ & 40 & 3.36 & 112 & 26.7 \\
\hline
\end{tabular}

TABLE 4

EFFECT OF LIGNIN PRODUCTS (40 KG HA ${ }^{-1}$ ), INTRODUCED IN SOIL BEFORE THE SOWING OF SEEDS ON THE ANTIOXIDANT ACTIVITY AND CONTENT OF POLYPHENOLS IN METHANOL EXTRACTS OF THE FRUITS AND HULLS

\begin{tabular}{|l|l|l|l|l|}
\hline Variant & $\begin{array}{l}\text { Rate of lignin products, } \\
\mathrm{kg} \mathrm{ha}^{-1}\end{array}$ & $\begin{array}{l}\text { Content of total } \\
\text { polyphenols, } \\
\text { GAE g per } 100 \mathrm{~g}^{*}\end{array}$ & Rutin, $\mathrm{mg} / 100 \mathrm{~g}^{*}$ & $\mathrm{IC}_{50}, \mathrm{mgL}^{-1} * *$ \\
\hline \multicolumn{5}{|l|}{ Hulls } \\
\hline Control & 0 & $0.52 \pm 0.01$ & 14.0 & 14.4 \\
\hline $\mathrm{LSi}$ & 40 & $0.53 \pm 0.01$ & 13.0 & 13.5 \\
\hline $\mathrm{L}$ & 40 & $0.49 \pm 0.01$ & 13.0 & 10.3 \\
\hline Grain & \multicolumn{5}{l}{} \\
\hline Control & 0 & $0.32 \pm 0.01$ & 3.0 & 90.7 \\
\hline $\mathrm{LSi}$ & 40 & $0.33 \pm 0.01$ & 3.3 & 68.3 \\
\hline $\mathrm{L}$ & 40 & $0.33 \pm 0.01$ & 3.2 & 67.3 \\
\hline
\end{tabular}

* in terms of the oven dry sample of biomass

** the concentration of the tested sample required for a $50 \%$ inhibition of radical species

Methanol extracts of the flour from the hulls and grain of buckwheat in comparison with those from flowers with bract, contained a small amount of polyphenols. Content of rutin was higher in the hulls, tah have shown a higher radical scavenging capacity (Table 3). Content of rutin in hulls extracts was 13.0$14.0 \mathrm{mg} / 100 \mathrm{~g}$ of dry mass, and in grain extracts only $3.0-3.3 \mathrm{mg} / 100 \mathrm{~g}$ of dry mass (Table 4). The results obtained have shown that in favourable vegetation conditions the quality parameters of buckwheat grain, including the content of rutin and polyphenols, can be comparable with this ones achieved in the regions with warm climate. The content of rutin in methanol extracts from the hulls and grain of buckwheat Fagopyrum esculentum Moench French, variety „La Harpe" was $5.2 \mathrm{mg} / 100 \mathrm{~g}$ dry mass and $2.3 \mathrm{mg} / 100 \mathrm{~g}$ dry mass, respectively [18]. The grain of the buckwheat cultivated in high-mountain areas in warm climate regions of Italy (1200 m above the sea level) the rutin content ranged from 5 to $58 \mathrm{mg} / 100 \mathrm{~g}$ of dry mass in the grain of common buckwheat of different varieties, cultivated in 2009 was docucmented [10]. Despite the absolute values of crop indicies obtained were lower than above mentioned in principle flowers with bract can be used as raw materials for rutin production.

\section{CONCLUSIONS}

Lignin preparations, introduced into soil jointly with buckwheat seeds during the sowing in quantities of $20 \mathrm{~kg} \mathrm{ha}^{-1}$ and $40 \mathrm{~kg} \mathrm{ha}^{-1}$, exerted a favourable effect on the development of plants and the synthesis of flavonoids in flowers with bract.

Flavonoids are represented mainly by rutin and quercetrin. The content of rutin in ethanol extracts from the biomass of flowers with bract, selected in the phase of accomplishing blooming - beginning of fruit formation, was $59 \%-65 \%$, and that of quercetrin $23 \%$ $28 \%$ from the total sum of components in the extract.

The rutin content in the biomass of flowers with bract in the phase of accomplishing blooming beginning of fruit formation in the variant with $40 \mathrm{~kg}$ $\mathrm{ha}^{-1}$ of Lignosilicon exceeded that in the control variant by $65 \%$ to be $2.74 \%$ in terms of dry mass. The raw material with such content of rutin can be used as an industrial raw material for obtaining rutincontaining pharmaceutical preparations.

Lignin preparations favoured the increase in the indices of the antioxidant activity of the alcohol extracts of the biomass of flowers with bract of buckwheat, as well as grain and hulls.

The increment of the buckwheat grain crop, in comparison with the control on the background of 20 $\mathrm{kg} \mathrm{ha}^{-1}$ and $40 \mathrm{~kg} \mathrm{ha}^{-1}$ of Lignosilicon and $40 \mathrm{~kg} \mathrm{ha}^{-1}$ of lignin, was $10 \%, 15 \%$ and $12 \%$, respectively.

\section{REFERENCES}

[1] I. Serǵe, G. Biteniece, G. Teliševa, G. Lebedeva, A. Lielpetere. Application of lignosilicon and azotobacterine for biological agriculture. - In Proc.: $4^{\text {th }} \quad$ Intern. Scientific and Practical Conference „, Environment. Technology. Resources”, Latvia, Rezekne, June 26-28, 2003, pp. 238-243.

[2] M. Spārniņa, S. Rancāne, G. Lebedeva, G. Teliševa. Lignosilīija pielietošana bioloğiskā lauksaimniecīiā ziemas 
rudzu sējumos. In Proc.: $5^{\text {th }}$ Intern. Scientific and Practical Conference „, Environment. Technology. Resources“, Latvia, Rezekne, June 16-18, 2005, pp.123-128.

[3] G. N. Lebedeva, G. M. Telysheva. Efficiency of the use of lignosilicon fertilizers and growth activators in cerials cultivation. - In Proc.: $2^{\text {nd }}$ Intern. Scientific Practical Conference "Earthworms and Soil's Fertility", Vladimir, Russia, March 17-19, 2004, chapter III, pp. 204-207.

[4] G. Lebedeva, G. Telysheva, S. Rancane, L. Tiltina. Application of lignosilicon in growing of red clover (Trifolium Pratense L.). In Proc.: $6^{\text {th }}$ Intern. Scientific and Practical Conference "Environment. Technology. Resources", Latvia, Rezekne, June 20-22, 2007, pp.141-149.

[5] G. Lebedeva, G. Telysheva, L. Tiltina, A. Volpert, Efficacy of Silicious Lignin Products Application for Biological Agriculture Exemplified by Experiments with Red Clovers, Proceedings of the $14^{\text {th }}$ International Meeting of the International Humic Substances Society, Moscow - Saint Petersburg, September 14-19, 2008, Vol. II, p.673 - 676.

[6] Г.Н.Лебедева, О.И.Трейкале, Г.М.Телышева. Эффективность применения лигнокремниевого препарата при выращивании томата и перца в защищённом грунте. Материаль II Международной научной конференщии. Регуляиия роста, развития и продуктивности растений. Минск, 5-8 декабря 2001 г., с. 122-123.

[7] G. Lebedeva, V. Solodovnik, G. Telysheva, J. Vigoskis, A Svarta, Use of lignosilicon to improve the harvest and quality parametrs of potato. - In Proc.: $8^{\text {th }}$ International Scientific and Practical Conference "Environment. Technology. Resources." Latvia, Rezekne, June 20-22, 2011, p.282-286.

[8] Lebedeva G., Teliševa G., Tiltiṇa L. Rancāne S. Lignosilīcija iestrāde reizē ar sēju un ta ietekme uz griḳu produktivitāti biologiskajā lauksaimniecībā. - In Proc.: $6^{\text {th }}$ Intern. Scientific and Practical Conference "Environment. Technology. Resources", Latvia, Rezekne, June 25 - 27, 2009, pp.118 124.

[9] Г.А.Романенко, „30 лет международной ассоциации исследователей гречихи (IBRA) - вехи и тенденции.” 11 ый международный симпозиум по гречихе. Вестник ОрелГАУ, 2010, N 4(25), c. 2-3.

[10] А. Брунори, Г. Бавиелло, М. Колонна, М. Рисси, Г. Иззи, М Тотх, Г. Вегвари, „Современное понимание перспектив возделывания и использования гречихи в Центральной и Южной Италии.” Вестник ОрёлГау, 2010, Nr.4(25), с. 2329.

[11] И. Крефт, К. Икеда, С. Икеда, Б. Вомбергар, „Разработка функционально новых продуктов питания на основе гречихи обыкновенной и татарской.” Вестник ОрелГАУ, 2010, N4(10), c.15-17.

[12] Н. В. Парахин, „Гречиха: биологические возможности и пути их реализации." 11 - ый международный симпозиум по гречихе.Вестник ОрелГАУ, 2010, N 4(10), с. 4-8

[13] Latvijas Centrāla statistikas pārvalde. www.csb.gov.lv

[14] Е. С. Алексеева, 3. П. Паушева, Генетика, селекиия и семеноводство гречихи. Киев. Издательство «Выща школа». 1988. с.208.

[15] Н. В. Фесенко, А. Н. Фесенко, О. И. Романова, „Морфологическая структура популяций как основной элемент функциональной системы экологической адаптации гречихи обыкновенной (Fagopyrum esculentum moench)." Вестник ОрёлГау, 2010, Nr. 4(25), с.47-52.

[16] H. Ghorbani Ghouzhdi, A. Sahraroo, A. Reza Yavari, M. Reza Amerian, „Effect of mist, irrigation and plant density levels on rutin content of common buckwheat (Fagopyrum esculentum Moench)". Journal of Food, Agriculture \& Environment, 2009 Vol. 7(1): pp.179-181.

[17] A. Baumgertel, A. Loebers, K. Wolfgang, „Buckwheat as a Source for The Herbal Drug Fagopyri herba: Rutin Content and Activity of Flavonoid- Degrading Enzymes during Plant Development." The European Journal of Plant Science and Biotechnology, 2010, pp. 82-86

[18] C. Quettier-Deleu , B. Gressier, J. Vasseur, T. Dine , C. Brunet, M. Luyckx , M. Cazin , J.C. Cazin , F. Bailleul, F. Trotin „Phenolic compounds and antioxidant activities of buckwheat (Fagopyrum esculentum Moench) hulls and flour.", 2000, Sep; 72(1-2), pp. 35-42.

[19] I. Kreft, N. Fabjan, M. Germ, „Rutin in buckwheat Protection of plants and its importance for the production of functional food." Fagopyrum, 2003, 20, pp. 7-11.

[20] [20] D. Li, X. Li, X. Ding, "Composition and Antioxidative Properties of the Flavonoid- rich Fractions from Tartary Buckwheat Grains.” Food ScienceBiotechnol, 2010, 19(3), pp. 711-716.

[21] C. H. Park, Y. B. Kim, Y. S. Chol, K. Heo, S. L. Kim, K. C. Lee, K. J. Chang, H. B. Lee, "Rutin content in food products processed from groats, leaves, and flowers of buckwheat." Fagopyrum, 2000, 17, pp. 63-66.

[22] М. М. Анисимова, Фармокогностическое исследование травы гречихи посевной (Fagopyrum sagittatum gilib.). Автореферат диссертации. Самара, 2011, 24 с.

[23] J. Bruneton, 1999. Pharmacognosie, Phytochimie, Plantes Medicinales, Techniques \& Documentation, Paris.

[24] Н. С. Ковальчук, Т. И. Куликова, Л. Д. Прусакова, А.Н. Фесенко, „Влияние биорегуляторов на морфофизиологические показатели и структуру урожая растений гречихи разных сортов.” Агрохимия, 2006, № 9, c. $46-51$.

[25] О. С. Мишина, С. Л. Белопухов, Л. Д. Прусакова, “Физиологичекие основы применения регуляторов роста циркона и карвитола для увеличения продуктивности гречихи.” Агрохимия, 2010, № 9, с. 42-54.

[26] А. В. Коротков, Л. Д. Прусакова, С. Л. Белопухов, А. Н. Фесенко, С. А. Тюрин, Ю. Г. Грицевич, „Влияние люрастима и бактериородопсина на урожай и качество зерна гречихи." Известия ТСXА, 2011, выпуск 1, с. 118123.

[27] Е. Л. Чайкина, Н. И. Герасименко, А. Г. Клыков, М. М. „Анисимов Влияние экстрактивных веществ бурой водоросли Laminaria cichorioides Miyabe на рост проростков и продуктивность растений гречихи." Агрохимия, 2011, № 3, с. 51-55.

[28] Reliable Prognosis: http://rp5.lv/Weather Diary in Skriveri

[29] G. Miliauskas, P. R Venskutonis, T. A. Van Beek, "Screening of radical scavenging activity of some medicinal and aromatic plant extracts." Food Chem., 2004, 85, pp. 231-237.

[30] N. Fabjan, J. Rode, I. Kosÿir, Z. Wang, Z. Zhang, I. Kreft, "Tartary Buckwheat (Fagopyrum tataricum Gaertn.) as a Source of Dietary Rutin and Quercitrin.” J. Agric. Food Chem., 2003, 51, pp. 6452-6455. 